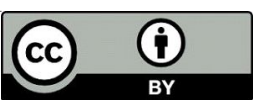

UDC $323.2 ; 316.3$

LBC $66.74 ; 60.56$
Submitted: 21.09 .2020

Accepted: 22.01.2021

\title{
CONTEMPORARY STATE AND PROSPECTS OF FEMALE PROTEST DEVELOPMENT: FROM DEPRIVATION TO MOBILIZATION ${ }^{1}$
}

\author{
Kirill M. Makarenko \\ Volgograd State University, Volgograd, Russian Federation
}

\section{Liliia S. Pankratova}

Saint Petersburg State University, Saint Petersburg, Russian Federation

\begin{abstract}
Introduction. The article presents the analysis of the contemporary state and prospects for the development of women's protest in a global perspective. The research focuses on the study of the causes and nature of mass women's protest in the context of the formation of a new system of relations between the authorities and society represented by certain social groups. The relevance of the problem is determined by the need for a political science analysis of modern practices, causes and forms of women's protest, making a forecast of the prospects for the development of women's social movements. Methods and methodology. The methodological basis of the research is the synthesis of the relative deprivation theory by T.R. Gurr and the resource mobilization theory by Ch. Tilly, which makes it possible to present women's protest through the prism of both psychological (deprivation) and institutional determinants. The empirical basis of the work is the data (338 cases) of the quantitative study "The Women in Resistance (WiRe)", that is available for secondary analysis in the Harvard Dataverse Repository. Analysis. Women's protests represent an institutional and non-institutional form of changing the "political field". A common peripheral role of women in the political space serves as a basis for the formation of a common identity among them. A high degree of consolidation, as well as an active role of women in protest, correlates with the success of collective action. Protests in which women play an active role are more peaceful in nature. This is due to the mediating role of women, which prevents the growth of tension in the conflict. Results. Based on the analysis of statistical information and case-study, it was revealed that the economic and legal structural similarity of states does not determine the nature of women's protest participation in politics, which is more dependent on historical practices, previously achieved results of women's protest, the presence of institutional structures that organize protests, as well as on the specific problems of women in the state. The prospects for the development of women's protest and women's social movements are determined by the level of success achieved. While in Western Europe and the USA, women's social movements are fighting for the achievement of postmaterial values, due to the solution of the economic differentiation problems, in Latin America, women are fighting for their natural right to life and their own bodies. A vector of women's protest is aimed at combating all types of $\vec{\sim}$ discrimination, but the nature of specific problems is fundamentally different.

ते Key words: women's protest, protest dynamics, political mobilization, women's social movements, politicization.

Citation. Makarenko K.M., Pankratova L.S. Contemporary State and Prospects of Female Protest Development: From Deprivation to Mobilization. Vestnik Volgogradskogo gosudarstvennogo universiteta. Seriya 4. Istoriya. Regionovedenie. Mezhdunarodnye otnosheniya [Science Journal of Volgograd State University. History. Area Studies. International Relations], 2021, vol. 26, no. 3, pp. 182-190. DOI: https://doi.org/10.15688/jvolsu4.2021.3.16
\end{abstract}




\title{
СОВРЕМЕННОЕ СОСТОЯНИЕ И ПЕРСПЕКТИВЫ РАЗВИТИЯ ЖЕНСКОГО ПРОТЕСТА: ОТ ДЕПРИВАЦИИ К МОБИЛИЗАЦИИ ${ }^{1}$
}

\author{
Кирилл Михайлович Макаренко \\ Волгоградский государственный университет, г. Волгоград, Российская Федерация
}

Лилия Сергеевна Панкратова

Санкт-Петербургский государственный университет, г. Санкт-Петербург, Российская Федерация

\begin{abstract}
Аннотация. Введение. Статья посвящена анализу современного состояния и перспектив развития женского протеста в глобальной перспективе. Фокус исследовательского внимания направлен на изучение причин и характера массового женского протеста в условиях формирования новой системы взаимоотношений между властью и обществом в лице определенных социальных групп. Актуальность проблемного поля обусловлена необходимостью политологического анализа современных практик, причин и форм женского протеста, составления прогноза перспектив развития женских социальных движений. Методы и методология. Методологическую основу исследования составляет синтез теории «относительной депривации» Т.Р. Гарра и теории мобилизации ресурсов Ч. Тилли, что позволяет представить женский протест через призму как психологических (депривационных), так и институциональных детерминант. Эмпирической базой работы послужили данные (338 кейсов) количественного исследования “The Women in Resistance (WiRe)” («Женщины в сопротивлении»), размещенные и доступные для вторичного анализа в репозитории Гарвардского университета (The Harvard Dataverse Repository). Анализ. Женские протесты представляют собой институциональную и неинституциональную форму изменения «политического поля». Основой для формирования общей идентичности у женщин выступает единая периферийная роль в политическом пространстве. Высокая степень консолидации, а также активная роль женщин в протесте коррелируют с успешностью коллективных действий. Протесты, где женщины играют активную роль, отличаются более мирным характером. Связано это, прежде всего, с посреднической ролью женщин, препятствующей нарастанию напряженности в конфликте. Результаты. На основе проведенного анализа статистической информации и case-study было выявлено, что экономическая и правовая структурная схожесть государств не обусловливает характер протестного участия женщин в политике, который в большей степени зависит от исторических практик, ранее достигнутых результатов женского протеста, наличия институциональных структур, организующих протест, а также от конкретных проблем женщин в государстве. Перспективы развития женского протеста и женских социальных движений определяются уровнем достигнугых успехов. В то время как в странах Западной Европы и США женские социальные движения борются за достижение постматериальных ценностей, вследствие решения проблем экономической дифференциации; в странах Латинской Америки женщины борются за свое естественное право на жизнь и право на собственное тело. Единый вектор женского протеста направлен на борьбу со всеми видами дискриминации, однако характер конкретных проблем коренным образом отличается. К.М. Макаренко систематизировал теоретико-методологические подходы к анализу женской протестной активности, провел анализ конкретных кейсов женского протеста в межстрановой перспективе. Л.С. Панкратова выделила критерии отбора стран для анализа практик женского протеста, сформулировала основные перспективы развития женского протеста, а также осуществила профессиональный перевод статьи на английский язык.
\end{abstract}

Ключевые слова: женский протест, протестная динамика, политическая мобилизация, женские социальные движения, политизация.

Цитирование. Макаренко К. М., Панкратова Л. С. Современное состояние и перспективы развития женского протеста: от депривации к мобилизации // Вестник Волгоградского государственного университета. Серия 4, История. Регионоведение. Международные отношения. - 2021. - Т. 26, № 3. - С. 182-190. (На англ. яз.). - DOI: https://doi.org/10.15688/jvolsu4.2021.3.16 


\section{ПРАКТИКИ ВЗАИМОДЕЙСТВИЯ ИНСТИТУТОВ ВЛАСТИ И ОБЩЕСТВА}

Introduction. Protest dynamics captures the state and nature of problems in society. The growth of protest moods and the manifestation of forms of protest activity indicates the emergence of new or actualization of existing problems. According to the wave principle of the spread of protests, the peak value is always replaced by a lull, when the principles of the concluded "social contract" are preserved in the nature of the relations of the "power-society" system. The breaking of this system indicates a revision (attempts to revise) of the established "rules of the game" and the formation of a new configuration of actors in the field of politics. In the context of the information society, women's protests, which are an active, passionate form of expressing public dissatisfaction with a certain social group, become an object of increasing public and research interest. As part of the global trend of the protest movement, women's protests often create the basis for the formation of a new protest wave, involving initially apolitical groups in the action.

The distinction of women's protest as a special social phenomenon is associated with a number of research problems. The first one is the definition of the criterion of its demarcation. Is a female protest something special? Should it be considered beyond just sexual differentiation? Or is it an individual case of a more general sample that does not have specific characteristics? Thus, the purpose of this study is to identify specific characteristics of modern women's protest and outline predictive scenarios of its development.

Methodology and methods. Within the framework of social and humanitarian knowledge, a number of schools and areas of thought focused on the study of the phenomena of mass protests, revolutions, riots, and various forms of collective action have been formed. In the research paper, we analyze and interpret women's political protest from the perspective of the theory of "relative deprivation" introduced by T.R. Gurr and resource mobilization theory worked out by $\mathrm{Ch}$. Tilly. The choice of the methodological basis of the work is objectified by the nature of a protest which has both psychological and institutional grounds. Relative deprivation, caused by a feeling of sharp rejection (frustration) of the social and political foundations of the social order, creates the basis for the growth of protest potential. The "explosion" of protest potential occurs in the case of successful institutional opportunities within the framework of "competitive politics". "Discontent arising from the perception of relative deprivation is the basic, instigating condition for participants in collective violence" [6, p. 54]. According to $\mathrm{Ch}$. Tilly's theory, the political system is an arena of "competitive politics," where power and counter-power compete for power and the amount of controlled resources. The way to fight depends on the capabilities of the system of mobilized resources and the "repertoire of collective actions". The authorities opposing concentrated women's discontent, expressed in mass collective action, have a rather limited "repertoire of actions".

The empirical basis of the work is the data (338 cases of mass actions that took place in 1945-2014) of the quantitative study "The Women in Resistance (WiRe)" [4], available in the Harvard Dataverse Repository. On the basis of a secondary analysis of the data, the features and trends of women's protest in various regions of the world were found out and analyzed.

Analysis. The practice of women's protests has more than 200 years of history and is associated with one of the most significant events that largely determined the subsequent development of political institutions around the world - the Great French Revolution. On the $5^{\text {th }}$ of October 1789, an event called "The Women's March on Versailles" took place. It is interesting that the anger of women was directed more towards Marie Antoinette than towards King Louis XVI. Women's protests and strikes at textile factories created a chain reaction that led to the February Revolution of 1917 in Russia. Women's protest primary was of an economic nature. But the unresolved problems in wages, social differentiation, and accumulated discontent associated with the war led to the politicization of collective protest actions and lead to the growth of the social base of the protest. Cases of civil (legal) protests aimed at solving the issue of women's emancipation are of great importance. The most significant events that directly influenced politics were the Woman suffrage parade of 1913, the 1956 Women's March in Pretoria, the 1975 Icelandic women's strike, the 2016 Polish abortion law protest, the 2016 Argentine Women's March against Violence. This list of specific historical events, published in The Guardian [14], does not 
define the extent of women's resistance around the world, but only records some of the most important historical moments that have changed political ideas about the role of women, their civil and political rights.

The issue of differentiation of collective actions remains significant. What is women's protest? What discontent among female citizens is about? What are the reasons for the protest? What is the government's repertoire of actions in response to female protests? Each of these questions requires the conduct of distinct surveys. In the article we reveal and discuss the results of some of the research.

From the point of view of the authors, the issue of politicizing women's participation in protest actions is extremely relevant and important in contemporary societies. The concept of L.E. Filippova, which points out the interdependence of the notions "political field" and "politicization", has major explanatory potential. Thus, the political field is a dynamic, institutionalized public space, where the practices of interaction between policy subjects on socially significant issues develop. "The formation of political identities, the growth of political activity, and an increase in the diversity of its forms and methods, the articulation and institutionalization of conflicts, the universalization of the norms and rules of interaction within the political community - all these processes can be considered as signs of the formation of a political field" [5, p. 98]. Politicization is the process of gaining political qualities by subjects, where there are following criteria: "propensity towards conflict, universalism of norms, the availability of choice and goal-setting" [5, pp. 98-99]. The fact of politicization of a socially significant problem is a reflection of the process of dynamic changes in the structure of the political field. If women's protests meet a number of criteria stated above, then this protest has political grounds and can be considered as an object of political science and studied by methods of political analysis. From our point of view, the most important criterion of politicization is propensity towards conflict, which determines the axiological nature of the problem. In this regard, it is necessary to appeal to the conflict as the main motivation for mobilizing women to participate in protest actions.

The basis for the formation of a common identity among women is their peripheral role in the political space. Success stories of women in politics is only an exception to the general principle of marginalization of the political role of women. The mobilization of the women's movement has strategic political goals aimed at obtaining certain preferences. Lisa Baldez, the author of the article "Why Women Protest", notes that the status of a woman, generally accepted in society and shared by its members, allows women to defend themselves against certain types of repression, forms of concentrated violence from the authorities. The status of women in protest actions becomes a mobilization resource, which provides women with the opportunity to perform actions that are prohibited for other groups [1, p. 21].

The study of women's protests is actively developing within the framework of the "competitive politics" approach. Thus, in the research conducted by A. Murdie and D. Peksen "Women and Contentious Politics: A Global EventData Approach to Understanding Women's Protest", based on the results of regression analysis (data were selected exclusively for nonviolent women's protests during 1991-2009), the authors checked a number of hypotheses and came to the following conclusions:

- Disrespect for basic human rights increases the probability of women's protests;

- Economic discrimination increases the probability of women's protest actions;

- The existence and active work of nongovernmental women's organizations contributes to the mobilization of women;

- The degree of economic well-being in a state affects the likelihood of women's protest actions;

- The total number of women in the country and its ratio to men is an important indicator of the number of women participating in protests;

- The connection between the political regime and women's protests is U-shaped. The likelihood of manifestation of women's protests in countries with a mixed (hybrid) regime is higher than in "pure" democracies and autocracies [11, pp. 187-188].

A. Murdie, D. Peksen, and S.R. Bell continued to investigate the issue of women's protests in a 2017 study. The main aim of the study was to identify the interconnection between globalization (economic, political, social) and the intensity of female and non-female anti- 


\section{ПРАКТИКИ ВЗАИМОДЕЙСТВИЯ ИНСТИТУТОВ ВЛАСТИ И ОБЩЕСТВА}

government protests. The authors came to the conclusion that globalization has a significant statistical effect on women's protests, but it practically does not affect non-women's protests. Thus, economic globalization, that mostly have an impact on historically disadvantaged social groups, is associated with a decrease in the intensity of women's protest. Political globalization also reduces the likelihood and intensity of women's protest due to the development of other instruments of influence on the political system from disadvantaged groups. At the same time, the social aspect of globalization leads to a statistically significant increase in female protest, as a result of the spread of ideas, resources, information flows, meaning organizational resources for mobilizing women's protest [2, pp. 21-22].

A research conducted by Harvard professor E. Chenoweth has a huge heuristic and explanatory potential for understanding the main traits of women's protest in the world. The study was based on the analysis of data on mass actions aimed at overthrowing dictatorships and giving the opportunity, right of territorial self-determination that took place during the period 1945-2014. An analysis of 338 cases (presented in the Harward Dataset "Women in Resistance") demonstrated a direct correlation between the participation of women in protest movements and the success of collective action [4]. The secondary analysis of the empirical data obtained by E. Chenoweth led us to the following findings:

- A sample of 146 cases $(43.1 \%$ of the total amount) of successful mass protest actions was obtained. In $59 \%$ of cases of successful mass collective actions (86 events) women were publicly qualified as the only or coalition leader (group of leaders).

- Calls for peace / peaceful demonstrations by women participating in protests were observed in $165(48.8 \%)$ out of a total of 338 cases. Calls for peaceful forms of collective action were expressed in $54.7 \%$ (80) of successful protests.

- In 161 cases out of 338 (47.6\%) means of violence were used against women by actors who are not part of the movement - from the "competing side": government forces, paid mercenaries, pro-government activists, etc.). In successful protests (146 cases), violence against women was used in 51 mass actions (35\%). Whereas, in the case of "failure" of protest actions
(192 events), violent actions against women took place in 110 cases $(57.2 \%)$.

Thus, based on the information presented in the WiRe Dataset, a number of conclusions can be made: 1) the active role of women increases the chances to obtain the goals manifested by protesters; 2) in the actions that had a positive outcome for the protesters, calls for peaceful forms of interaction were more often declared; 3 ) the use of various forms of violence against women in successful campaigns is much lower than in the general set of cases.

Findings regarding the reduction in violence in mass protests involving women are confirmed by the report "Understanding the Role of Women and Feminist actors in Lebanon's 2019 Protests". Thus, the authors of the report note the buffer role of women, that prevents the growth of tension between protesters and security forces. The special role of older women in mass protests, which emotionally affect employees of progovernment services, is noted. The concept of motherhood, which is especially revered in Lebanese society, is used as a mobilization resource. The dialogue with security officials includes the emotional pressure in such phrases, as: "Don't harm us, I could be your mom" [18].

The principle of women's participation in politics varies greatly across countries. It is worth paying attention to the available data on the gender pay gap, the proportion of women and men in senior and middle management positions, and the index of women's economic opportunities. Based on the data presented on the site "Our world in Data", we can conclude that the economic position of women in relation to men in Latin America (Brazil, Mexico, Argentina, Uruguay, Chile) and Russia is extremely similar [12]. There is no significant difference in any of the above three criteria. According to the data presented in the 2017 Human Rights Scores, Russia, Brazil, Argentina, and Mexico are at about the same level of the observance of human rights, while Belarus is placed higher in this rating. Chile, according to the index, is on a par with the countries of Southern Europe and Australia [15]. Economic and legal structural similarities do not determine the nature of protest participation of women in politics. To explain the reasons for the discrepancy in the principles of female participation, we use the case study method to scrutinize specific examples in order to form generalizing conclusions. 
The nature of protest activity in Latin America and the CIS (Commonwealth of Independent States) is fundamentally different. The examples of protest practice in 2019-2020 in Latin American countries, such as Brazil, Argentina, Mexico, and Chile, are characterized by: 1) a high degree of consolidation of women in collective actions aimed at combating genderbased violence; 2) not spontaneous, but institutional nature of the protest, usually held on International Women's Day on March 8. An article written by Helen Icken Safa on women's social movements in Latin America notes that movement formation is the result of a number of interrelated processes: 1) destruction of the traditional division between private and public life; 2) reduction of the role of the family, the inclusion of women in the labor force; 3) absence of the real equality between men and women. Women's social movements in Latin America was a response to the military authoritarian rule and the economic crisis, which was associated with the destruction of the traditional family sphere and the inclusion of women as workers with less economic needs [16, pp. 355-356]. According to the France 24 news agency, the scale of the protests on International Women's Day in Latin America on the $8^{\text {th }}$ of March 2020 reached several hundred thousand people. The main issues of the protest discourse were about economic gender inequality, the increase in the number of murders of women, abortion control, etc. [7].

Mexican women's protests, in addition to common features for Latin America, tend to involve actionism. A high degree of solidarity on the $8^{\text {th }}$ of March 2020 in Mexico City was demonstrated during the "Day Without Us" campaign. In public places, transport, there were fewer women than usually, school classes and university lectures were boycotted. It was noted that the women who worked on March 8 expressed solidarity with the ideas of the action with the purple ribbons and clothes [10]. The Chilean experience of the women's protest movement is interesting in this regard. The high level of self-organization and coordination of collective actions displayed by Chilean women during the reign of Augusto Pinochet demonstrates sufficiently large mobilization resource. Almost half a century after the fall of the Pinochet regime, women remain a significant political force in the country. The scale of collective actions on International Women's Day reaches 1 million people. The slogans point out the important role of women and the demands of social, economic transformations [9]. The main theme of women's protests in Chile (as well as in Argentina) in 2020 was the demand for support of the right to abortion, symbolized by green bandanas around the neck. Argentine protests in 2019 and 2020 were held under the slogan against female violence and the demand of abortion legalization. The personalized nature of female protest was only in Brazil in 2019. The main criticism of the protesters was directed at President Jair Bolsonaro, who was accused of falsification of information on gender violence and offensive comments on women [3].

The cases of Russia and Belarus are extremely different from the Latin American ones: there is another scope of the discussed problems, distinct way in the genesis of the women's movement in these countries. Interestingly, according to the report "Counter mobilization. Moscow Protests and Regional Elections - 2019", based on the research of demographical aspects of the protest conducted by A. Arkhipova, A. Zakharov, I. Kozlova, and M. Gavrilova, the standard ratio of the proportion of male and female participants of mass collective actions - "60 to 40 " - is changing. During the period 2011-2019 the proportion of women in protests increased from $34 \%$ to $44 \%$. The willingness of women to take up posters and thereby not only publicly express their position, but also expose themselves to additional risks, has gradually increased in recent years. As noted in the report, at the mass protest action on the 10th of August 2019, the number of men and women holding posters was the same [17, p. 63]. Actions in support of the Khachaturian sisters, as well as general demands for the fight against any form of discrimination, were significant incentives for the consolidation of the women's protest movement in 2020. However, taking into account the low level of involvement of women in Russia in active protest activities, we come to a conclusion that consolidating slogans, theses, and messages are inconsistent. Participation in the movement is determined by the possibility of extrapolating the interests of the movement to the interests of specific individuals, which, apparently, does not happen in the modern Russian women's movement. 


\section{ПРАКТИКИ ВЗАИМОДЕЙСТВИЯ ИНСТИТУТОВ ВЛАСТИ И ОБЩЕСТВА}

An opposite practice of protest activity was in the Republic of Belarus in 2020. The presidential elections in the Republic of Belarus, held on the $9^{\text {th }}$ of August 2020, led to massive discontent, accusations of falsification of the election results, and a series of spontaneous political protest actions. The women's protest in Belarus is an extraordinary form of mobilization and a unique protest experience for the CIS countries, it is similar to the mass collective actions in some other countries and regions in the world. The women's protest in Belarus is the result of a "competitive politics" between the government, represented by President A. Lukashenko, and opposition forces (the Coordination Council of the Opposition), which disagreed with the announced results of the elections. The first days of the protest (from the $9^{\text {th }}$ to $12^{\text {th }}$ of August) were characterized by the highest rates of violence: more than 6,000 detainees and more than 200 injured [13]. Starting from the $12^{\text {th }}$ of August, "chains of solidarity" are being organized in Belarus. The main idea of manifested calls for a peaceful resolution of the political crisis - "female strength is in weakness". Since the $13^{\text {th }}$ of August, "women's marches" have been held in many cities of the Republic [8]. The personification of authority and the formation of the image of the "father of the nation" or "Father", as Alexander Lukashenko is called in the CIS countries, is associated with the function of protection. This idea Lukashenko emphasizes in almost every public speech. The violent suppression of women's mass collective actions carries greater costs than acquisitions for the authorities - the desacralization of the role of protector is the most important problem.

Results. An analysis of specific cases allows us to draw a number of conclusions about the current state of women's protests. Women's protests arise and become widespread when individual discontent acquires the characteristic of "relative deprivation" and is mobilized by political actors, public institutions, and nongovernmental organizations. Women's protests in many regions of the world are characterized by a high degree of consolidation and mobilization. Women's protests in Latin America have strong institutional foundations as the result of a long history of public expression of discontent and importance, high status of trade unions in the societies. The protest actions in the CIS countries have the spontaneous nature of resistance as a response to an extraordinary situation. The women's protests are devoted to both exclusively female problems and issues of a general social significance: social policy, economic policy, alternation of power, etc. The women's protests have the greatest effect under the authoritarian and hybrid regimes, the sociocommunication conditions of which help to construct the opposition between strong ruler and weak nationals. Women's protests in the world are becoming more massive, organized, and subjectfield-driven due to a global change in the political field and the demarginalization of the peripheral political role of women. In this regard, the question of the prospects of women's protest is considered relevant.

According to the principles of political mobilization, the global trend in the development of the women's movement, primarily in the periphery and semi-periphery countries, will be the formation of the institutional foundations of the protest: the emergence of organizational and coordination structures, foundations, forums, etc., contributing to the formation of the subjectivity of the women's movement. There is a high likelihood of the formation of regional integration structures and network cooperation in order to promote common goals, in accordance with a common protest agenda. The spread of modern information and communication technologies, primarily the Internet, on the one hand, gives sociocommunicative tools for the implementation of integration trends (for example, the formation of online social movements and networks). On the other hand, it provides a new virtual space for expressing women's non-violent protest in various communicative forms, degree of involvement (creation and distribution of photo and video content, online (co)participation in rallies, etc.). The digitalization of protest activity can contribute to both the use of new channels of communication with the authorities on conflict issues, and solidarity, strengthening ties within a movement, as well as expanding the social base of the mass collective action by engaging new participants.

The prospects for the development of women's protest and female social movements are determined by the level of success already achieved. While in the countries of Western Europe and the USA, women's social movements 
are fighting for the achievement of post-material values due to the solution of the problems of economic differentiation, progress towards the creation of an egalitarian gender order in society, as well as a significant transformation of gender regimes of social institutions, including political ones; women in Latin America are fighting for their natural right to life and their right to their own bodies. A single, common vector of women's protest is aimed at combating all types of discrimination, but the character of particular problems is fundamentally different.

\section{NOTE}

${ }^{1}$ The article was prepared based on the results of studies carried out in the framework of the project funded by RFBR and EISR № 20-011-31676.

\section{REFERENCES}

1. Baldez L. Why Women Protest: Women's Movements in Chile. Cambridge, Cambridge University Press, 2002. $227 \mathrm{p}$.

2. Bell S.R., Murdie A., Peksen D. Globalization and Contentious Politics: Predicting Women's and Non-Women's Protest, 2017. URL: http://www. amandamurdie.org/uploads/3/4/3/2/34329007/bell murdie_peksen_2017.pdf (accessed 29 December 2020).

3. Calavatra A., Rey D. International Women's Day: Strikes, Protests and Holidays. AP News. March 9, 2019. URL: https://apnews.com/35cb80ff $96 \mathrm{cb} 410$ baf875c07f9d96c67 (accessed 2 September 2020).

4. Chenoweth E. "WiRe Dataset, v1.xls", Women in Resistance Dataset, version 1. Harvard Dataverse, V3. 2019. URL: https://doi.org/10.7910/ DVN/BYFJ3Z/6AURFD (accessed 2 September 2020).

5. Filippova Ye.L. «Politizatsiya» vs «depolitizatsiya»: poisk al'ternativnykh strategicheskikh proyektov i vozmozhnosti strukturirovaniya politicheskogopolya ["Politicization" vs "Depoliticization": The Search for Alternative Strategic Projects and Possibilities of Political Field Structuring]. Politicheskaya nauka [Political Science], 2018, no. 2, pp. 95-115.

6. Gurr T.R. Pochemu lyudi buntuyut [Why Men Rebel]. Saint Petersburg, Piter Publ., 2005. 461 p.

7. Huge Protests in Latin America on International Women's Day. France 24. March 9, 2020. URL: https://www.france24.com/en/20200309-huge- protests-in-latin-america-on-international-women-sday (accessed 2 September 2020).

8. «Lukashenko nas sil'no nedootsenil». Kak zhenshchiny $\mathrm{v}$ Belorussii stali moshchnoy siloy protestnogo dvizheniya ["Lukashenko Greatly Underestimated Us" How Women in Belarus Became a Powerful Force of the Protest Movement]. Lenta.ru. URL: https://lenta.ru/articles/2020/08/22/belwomen/ (accessed 2 September 2020).

9. McGovan C. "Our Role is Central": More than $1 \mathrm{~m}$ Chilean Women to March in Huge Protest. The Guardian. 6 March 2020. URL: https://www. theguardian.com/world/2020/mar/06/chile-womensday-protest (accessed 3 September 2020).

10. Mexican Women Strike to Protest Against Gender-Based Violence. BBC News. 9 March 2020. URL: https://www.bbc.com/news/world-latin-america51811040 (accessed 2 September 2020).

11. Murdie A., Peksen D. Women and Contentious Politics: A Global Event-Data Approach to Understanding Women's Protest. Political Research Quarterly, 2015, vol. 68 (1), pp. 180-192.

12. Ortiz-Ospina E. Economic Inequality by Gender. 2018. URL: https://ourworldindata.org/economicinequality-by-gender_(accessed 29 August 2020).

13. Posledniye dannyye po protestam v Belorussii. Statistika i khronika protivostoyaniya [The Latest Data on Protests in Belarus. Statistics and Chronicle of the Confrontation]. Kommersant. URL: https://www.kommersant.ru/doc/4451480\#id1932303 (accessed 2 September 2020).

14. Puglice N. How these Six Women's Protests Changed History. The Guardian. January, 212017. URL: https://www.theguardian.com/world/2017/jan/21/ womens-march-protests-history-suffragettes-icelandpoland (accessed 29 August 2020).

15. Roser M. Human Rights. 2016. URL: https:// ourworldindata.org/human-rights (accessed 29 August 2020).

16. Safa H.I. Women's Social Movements in Latin America. Gender and Society, 1990, vol. 4, no. 3, pp. 354-369.

17. Rogova K., ed. Vstrechnaya mobilizatsiya. Moskovskiye protesty i regional'nyye vybory 2019: analiticheskiy doklad. Seriya "Liberal'naya missiya-Ekspertiza». Vyp. 7 [Counter Mobilization. Moscow Protests and Regional Elections - 2019. Analytical Report. Series "Liberal Mission Expertise". Iss. 7]. Moscow, Fond "Liberal'naya missiya", 2019.110 p.

18. Wilson C., Zabaneh J., Dore-Weeks R. Understanding the Role of Women and Feminist Actors in Lebanon's 2019 Protests. UN Women, 2019. 17 p. 


\section{ПРАКТИКИ ВЗАИМОДЕЙСТВИЯ ИНСТИТУТОВ ВЛАСТИ И ОБЩЕСТВА \\ Information About the Authors}

Kirill M. Makarenko, Senior Lecturer, Department of International Relations, Political Sciences and Area Studies, Volgograd State University, Prosp. Universitetsky, 100, 400062 Volgograd, Russian Federation, makarenko_km@volsu.ru, https://orcid.org/0000-0002-1161-5719

Liliia S. Pankratova, Candidate of Sciences (Sociology), Associate Professor, Department of Sociology of Culture and Communication, Saint Petersburg State University, 7/9 Universitetskaya emb., 199034 Saint Petersburg, Russian Federation, 1.s.pankratova@spbu.ru, https://orcid.org/0000-0002-7658-1409

\section{Информация об авторах}

Кирилл Михайлович Макаренко, старший преподаватель кафедры международных отношений, политологии и регионоведения, Волгоградский государственный университет, просп. Университетский, 100, 400062 г. Волгоград, Российская Федерация, makarenko_km@volsu.ru, https://orcid.org/0000-0002-1161-5719

Лилия Сергеевна Панкратова, кандидат социологических наук, доцент кафедры социологии культуры и коммуникации, Санкт-Петербургский государственный университет, Университетская наб., 7/9, 199034 г. Санкт-Петербург, Российская Федерация, 1.s.pankratova@spbu.ru, https://orcid.org/0000-0002-7658-1409 